\title{
Mononuclear Transition Metal Complexes of 7-Nitro-1,3,5-Triazaadamantane
}

\author{
Gabriele Wagner, ${ }^{*[a]}$ Peter N. Horton ${ }^{[b]}$ and Simon J. Coles ${ }^{[b]}$ \\ [a]: Department of Natural Sciences, University of Chester, Thornton Science Park, Pool Lane, Ince, Chester, CH2 4NU, \\ United Kingdom. E-mail: g.wagner @chester.ac.uk
}

[b]: National Crystallography Service, School of Chemistry, University of Southampton, Southampton SO17 1BJ, United Kingdom.

\begin{abstract}
Complexes of the type $\left.\left[\mathrm{MCl}_{2} \text { (7-nitro-1,3,5-triaza-adamantane) }\right)_{2}\right] \quad(\mathrm{M}=\mathrm{Zn}(\mathrm{II}), \mathrm{Pd}(\mathrm{II}), \mathrm{Pt}(\mathrm{II}))$ and $\left.\left[\mathrm{MCl}_{2}\left(\mathrm{H}_{2} \mathrm{O}\right)_{2} \text { (7-nitro-1,3,5-triazaadamantane) }\right)_{2}\right](\mathrm{M}=\mathrm{Mn}(\mathrm{II}), \mathrm{Co}(\mathrm{II}), \mathrm{Ni}(\mathrm{II})$ ) have been prepared and their structures have been analysed by X-ray crystallography, elemental analysis, IR and solid state ${ }^{13} \mathrm{C}$ and ${ }^{15} \mathrm{~N} N M R$ spectroscopy, supported by density functional theory/gauge independent atomic orbital (DFT/GIAO) calculations. In each case, 7-nitro-1,3,5-triazaadamantane acts as a mono-dentate ligand and binds to one metal centre only, in spite of the presence of three equivalent amino nitrogens. In the Co(II) and $\mathrm{Ni}$ (II) complexes, a two-dimensional intermolecular hydrogen bonding network between the aqua- and the chloro ligands is established. The uncoordinated amines of the 7-nitro-1,3,5-triaza-adamantane are not involved in any $\mathrm{H}$ bonding, as a result of the exceptionally low basicity of this compound.
\end{abstract}

\section{Introduction}

Organic compounds with nitrogen atoms in 1,3 position to each other show interesting properties due to nonbonding interactions based on homoconjugation between the nonbonding orbitals at N. ${ }^{[1]}$ This so called $1,3, n, n$ interaction is particularly pronounced in azaadamantanes where the nitrogens occupy bridgehead positions in a rigid cage, as in the case of 1,3,5,7-tetraaza-adamantane (better known as hexamethylenetetramine, hmta). The communication between the nitrogen atoms is evident from the typical chemistry of these compounds. The pKa value of $4.89^{[2]}$ of the protonated species hmta-H+ is much lower than that of organic $\mathrm{R}_{3} \mathrm{~N}-\mathrm{H}^{+}$(pKa $\left.10-11\right)^{[3]}$ and $\mathrm{NH}_{4}{ }^{+}$(pKa 9.2), ${ }^{[4]}$ indicative of a fairly low basicity of the parent amine hmta. In aqueous systems hmta is mono-protonated only, whereas diprotonation, with a pKa of -2 , requires addition of strong acids and leads to decomposition of the hmta framework. ${ }^{[\mathrm{b}]}$ Likewise, the metal coordination is compromised, in a sense that coordination to one of the nitrogens alters the coordination behaviour of the others. The coordination pattern is most diverse with $\mathrm{Ag}(\mathrm{I})$, where hmta acts as a tetradentate, tridentate or bidentate ligand leading to three dimensional structures, ribbons, sheets or chains. ${ }^{[5]}$ With other metals, tetradentate ${ }^{[6]}$ and tridentate ${ }^{[7]}$ coordination modes have occasionally been observed as well, but bidentate ${ }^{[8]}$ and monodentate binding ${ }^{[9]}$ is far more typical. There are also many examples where hmta is found in the crystal packing without coordination to a metal centre. In these cases, hydrogen bonding between hmta and the metal coordinated ligands is observed. ${ }^{[10]}$

Among the adamantanes bearing three bridgehead nitrogens, 7-phospha-1,3,5-triazaadamantane and the corresponding phosphinoxide and phosphinsulfide have been studied in quite some detail, in particular with respect to bimetallic complexes where one metal coordinates to the $\mathrm{P}$ atom and the other is attached to one of the nitrogens, ${ }^{[11]}$ or where the $\mathrm{P}=\mathrm{O} / \mathrm{S}$ moiety coordinates through the $\mathrm{O}$ and $\mathrm{S}$ atoms. ${ }^{[12]} \mathrm{N}$-coordinated mononuclear complexes have also been characterised. ${ }^{[12 b, 13]}$ These form with hard metal centres whose preference for $\mathrm{P}$ is low.

The monodentate coordination pattern is also seen with a related 7-methyl-1,3,5-triazaadamantane derivative, which coordinates $\mathrm{Fe}(\mathrm{II})$ to one of the $\mathrm{N}$ atoms. ${ }^{[14]}$ 1,3,5-triazaadamantanes bearing heterocyclic substituents such as pyridine or imidazole have been found to undergo aminal imine rearrangement in the presence of $\mathrm{Fe}(\mathrm{II})$, and hexadentate tri-imine complexes are formed. ${ }^{[14,15]}$

7-Nitro-1,3,5-triazaadamantane ( $\mathrm{NO}_{2}$-TAA) tends to mono- and bidentate behaviour, as far as one can conclude from the few examples studied so far. These consist of bidentate $\mathrm{Ag}(\mathrm{I})$ and $\mathrm{Hg}(\mathrm{II})$ complexes, which were 
characterised in the solid state by single crystal X-ray diffraction, and $\mathrm{Hg}(\mathrm{II}), \mathrm{Zn}(\mathrm{II}), \mathrm{Cd}(\mathrm{II})$ and $\mathrm{Pb}(\mathrm{II})$ complexes whose ligand to metal stoichiometry was determined in $\mathrm{CH}_{3} \mathrm{CN}$ solution. ${ }^{[16]}$ The ${ }^{1} \mathrm{H}$ NMR spectra of these complexes point to dynamic behaviour and rapid ligand exchange because the ligand signals shift but do no split in consequence of the reduced symmetry in the coordinated state. The lability is also manifested in the different composition of the $\mathrm{Hg}$ (II) complexes, which contain two ligands per metal in solution but only one in the solid state. ${ }^{[16]} \mathrm{Pt}(\mathrm{II})$ forms kinetically stable complexes, as shown by multinuclear NMR spectroscopy in $\mathrm{CHCl}_{3}$ solution. Stoichiometry control allows for the selective synthesis of mononuclear compounds where $\mathrm{NO}_{2}$-TAA binds in a monodentate manner. However, the corresponding dinuclear species were obtained as by-products or when two equivalents of the $\mathrm{Pt}(\mathrm{II})$ precursor were used, ${ }^{[17]}$ suggesting that the bidentate binding mode might be preferred. In this aspect, $\mathrm{NO}_{2}$-TAA closely resembles the behaviour of $\mathrm{hmta}$ as a ligand. ${ }^{[18]}$

In the present work, we describe the synthesis and solid state analysis of a series of new mononuclear transition metal complexes with $\mathrm{NO}_{2}$-TAA. These are the first examples where this ligand binds in a monodentate manner without the need for stoichiometric control, and where no aggregation to polynuclear species takes place upon crystallisation.

\section{Results and Discussion}

(a) Synthesis and characterisation of the ligand: The ligand 7-nitro-1,3,5-triazaadamantane 1 was synthesised from nitro-methane, paraformaldehyde and ammonium acetate as shown in Scheme 1, using a modified procedure from the literature. ${ }^{[19]}$ Alternatively, 1 can be prepared from hexa-methylenetetramine, formic acid and nitromethane, ${ }^{[20]}$ or from tris(hydroxymethyl)nitro-methane, para-formaldehyde and ammonia in similar yields. ${ }^{[19 a]}$

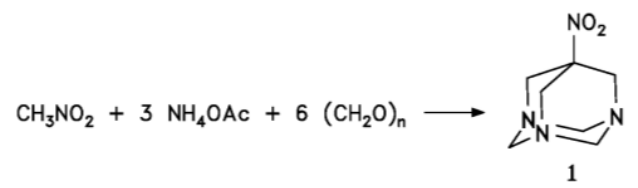

Scheme 1. Synthesis of 7-nitro-1,3,5-triazaadamantane.

Elemental analysis, mass spectrometry, IR and NMR spectroscopic data confirm the structure of the compound. The ${ }^{1} \mathrm{H}$ NMR data in $\mathrm{CDCl}_{3}$ agree well with literature data in $\mathrm{CD}_{3} \mathrm{CN}^{[16]}$ and in $\mathrm{CD}_{3} \mathrm{COOD}^{[21]}$ In $\mathrm{CDCl}_{3}$ solution, the spectrum displays a 6 proton singlet at $3.83 \mathrm{ppm}$ for the $\mathrm{C}-\mathrm{CH}_{2}-\mathrm{N}$ protons, and two doublets at 4.12 and 4.48 ppm accounting for 3 protons of the axial and equatorial protons of the $\mathrm{N}-\mathrm{CH}_{2}-\mathrm{N}$ groups. The signal of the axial protons is at higher chemical shift than that of the equatorial ones, as confirmed from ${ }^{1} \mathrm{H}$ NOE experiments. The two types of protons couple to each other with a geminal coupling constant of $13.2 \mathrm{~Hz}$, and the lines of each signal are slightly broadened due to an unresolved long range coupling to the $\mathrm{C}-\mathrm{CH}_{2}-\mathrm{N}$ protons. The ${ }^{13} \mathrm{C} N M R$ spectrum shows three signals at $59.7\left(\mathrm{C}-\mathrm{CH}_{2}-\mathrm{N}\right), 72.6\left(\mathrm{C}-\mathrm{NO}_{2}\right), 73.4\left(\mathrm{~N}-\mathrm{CH}_{2}-\mathrm{N}\right) \mathrm{ppm}$. The ${ }^{13} \mathrm{C}$ MAS-CP NMR in the solid state suggests that the rotation of the nitro group is blocked, and the compound is less symmetric than in solution. The $\mathrm{C}-\mathrm{CH}_{2}-\mathrm{N}$ groups appear as two signals at 56.6 and $59.4 \mathrm{ppm}$, in a ratio $2: 1$, whereas the $\mathrm{N}-\mathrm{CH}_{2}-\mathrm{N}$ resonance at $71.8 \mathrm{ppm}$ accounts for three carbons. The quaternary carbon at $74.1 \mathrm{ppm}$ was identified by its disappearance at short $(50 \mu \mathrm{s}) \mathrm{CP}$ contact time. The $\mathrm{CH}_{2}$ groups are more shielded and the quaternary $\mathrm{C}$ is less shielded than in $\mathrm{CDCl}_{3}$ solution. ${ }^{15} \mathrm{~N}$ MAS-CP NMR spectra, run at natural abundance against external glycine = $+12.5 \mathrm{ppm}$ as a reference $\left({ }^{15} \mathrm{NH}_{4} \mathrm{NO}_{3}=0 \mathrm{ppm}\right.$ scale $\left.{ }^{[22]}\right)$, show the amine nitrogens at $28.4 \mathrm{ppm}$ but the $\mathrm{NO}_{2}$ group was not detected. On the basis of the nuclear properties of ${ }^{15} \mathrm{~N}$ this is a plausible result. The typical ${ }^{15} \mathrm{~N}$ relaxation times $\mathrm{T} 1$ of amines can vary widely but the nuclear Overhauser enhancement factors are usually fairly favourable (e.g. ${ }^{\mathrm{B}} \mathrm{BuNH}_{2} 70 \mathrm{~s} / \mathrm{NOE}-3.9,{ }^{[23]}$ quinuclidine approx. $1300 \mathrm{~s},{ }^{[24]}$ indole NH $3.5 \mathrm{~s}$, heterocyclic tertiary N $25 \mathrm{~s}$, NOE $-5.0^{[25]}$ ), whereas nitro groups relax very slowly (e.g. T1 of nitrobenzene: $400 \mathrm{~s}^{[26]}$ or $180 \mathrm{~s}^{[27]}$ ) and display unfavourable NOE factors near -1 (e.g. $\left(\mathrm{HOCH}_{2}\right)_{2} \mathrm{CMeNO}_{2}-1.0{ }^{[24]}$ ). The chemical shift of the $\mathrm{NO}_{2}$-TAA amines is quite different from that of simple aliphatic amines (typically $2 \mathrm{ppm}{ }^{[28]}$ ) but comparable to that of hmta (26.5 $\mathrm{ppm}^{[29]}$ ) where the nitrogens are also subject to $1,3, \mathrm{n}, \mathrm{n}$ interactions. From the slightly higher chemical shift in 
$\mathrm{NO}_{2}$-TAA one might anticipate a lower charge density at $\mathrm{N}$ than in hmta. This is in good agreement with results obtained from DFT calculations ${ }^{[18]}$ and also compatible with the extremely low pKa value of the protonated $\mathrm{NO}_{2}$ TAA $\left(3.42,{ }^{[18]}\right.$ as compared to 4.89 in protonated $\left.h m t^{[2]}\right)$. There is also evidence from IR and electronic spectroscopy for a charge transfer from the $\mathrm{N}$ atoms to an antibonding orbital of the $\mathrm{NO}_{2}$ group, ${ }^{[30]}$ which of course is absent in hmta.

(b) synthesis and characterisation of the complexes: The synthesis of the transition metal complexes, outlined in Scheme 2, was guided by the relatively poor solubility of the ligand in most solvents. ${ }^{[16]}$ Near saturated solutions of $\mathrm{NO}_{2}-\mathrm{TAA}$ in $\mathrm{CH}_{2} \mathrm{Cl}_{2}$ (solubility $1.7 \pm 0.8 \cdot 10^{-1} \mathrm{~mol} \mathrm{dm}^{-3}$ ) were carefully covered with a ethanol solution of the metal salt $\left(\mathrm{ZnCl}_{2}, \mathrm{MnCl}_{2} \cdot 4 \mathrm{H}_{2} \mathrm{O}, \mathrm{CoCl}_{2} \cdot 6 \mathrm{H}_{2} \mathrm{O}, \mathrm{NiCl}_{2} \cdot 6 \mathrm{H}_{2} \mathrm{O}\right)$ and crystals of the complex were grown by slow diffusion. Independent of the ligand to metal ratio, which was varied from 4:1 to 1:1, complexes with a 2:1 stoichiometry formed as the sole products, except for $\mathrm{Co}(\mathrm{II})$ where small amounts of oligomeric side products with a 3:2 and 4:3 stoichiometry were detected. In the case of $\mathrm{Zn}(\mathrm{II})$ this is in contrast to the previously described complexes where a 1:1 stoichiometry was found in $\mathrm{CH}_{3} \mathrm{CN}$ solution. ${ }^{[16]}$ The $\mathrm{Pd}(\mathrm{II})$ and $\mathrm{Pt}(\mathrm{II})$ complexes were obtained from $\left[\mathrm{MCl}_{2}(\mathrm{PhCN})_{2}\right]$ by ligand exchange in dichloromethane solution, or starting from $\mathrm{PdCl}_{2}$ or $\mathrm{K}_{2}\left[\mathrm{PtCl}_{4}\right]$ in DMF or aqueous solution. The former reaction occurs via the intermediacy of the mixed ligand $\left[\mathrm{MCl}_{2}(\mathrm{PhCN})\left(\mathrm{NO}_{2}-\mathrm{TAA}\right)\right]$ complex, which, in the case of $\mathrm{Pt}(\mathrm{II})$, could be isolated and characterised.

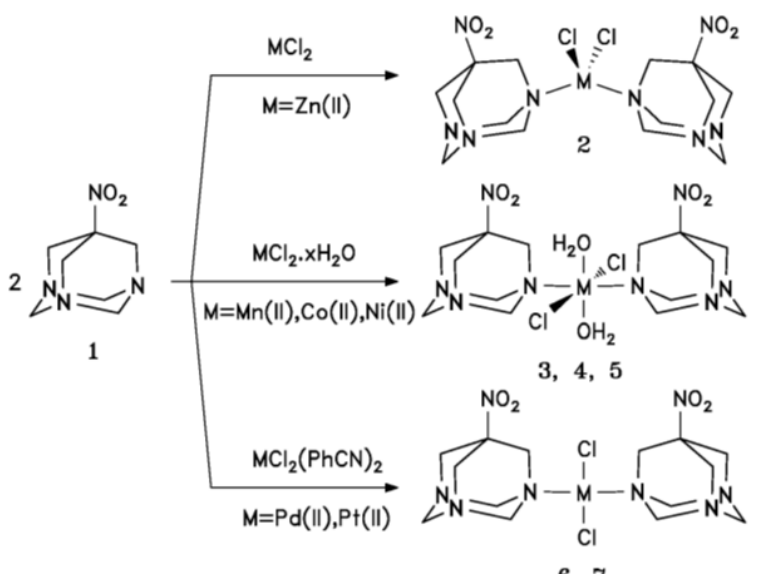

6, 7

Scheme 2. Synthesis of the transition metal complexes.

Elemental analyses confirmed the molecular formula attributed to the complexes. In the IR spectrum, the $\mathrm{NO}_{2}$ asymmetric stretch is shifted to higher wavenumbers and shows as two lines, since two ligands are present in the molecule. Also the $\mathrm{CH}_{2}$ scissoring is seen at slightly higher wavenumbers, and the signals associated with the fundamentals of the azaadamantane cage in the fingerprint region split into several lines due to the lower symmetry of the coordinated ligand. From the general IR pattern one can group the complexes into three classes: Those of $\mathrm{Mn}(\mathrm{II}), \mathrm{Co}(\mathrm{II})$ and $\mathrm{Ni}\left((\mathrm{II})\right.$ contain coordinated $\mathrm{H}_{2} \mathrm{O}$ molecules which are identified by the characteristic strong symmetric and asymmetric $\mathrm{O}-\mathrm{H}$ stretching vibrations in the range of 3390 to $3220 \mathrm{~cm}^{-1}$ and a $\mathrm{H}-\mathrm{O}-\mathrm{H}$ bending vibration at $1613-1615 \mathrm{~cm}^{-1}$. The spectra are nearly super-imposable, indicating that these complexes are structurally similar. Among the water-free compounds, the IR of the Pd(II) and Pt(II) complexes are almost identical, but quite different from that of the $\mathrm{Zn}$ (II) complex. This reflects the different coordination geometry which is square planar in the former and tetrahedral in the latter. DFT calculations (B3LYP/6-31G* and Lan2DZ for Pd and Pt) were used to assist the spectra interpretation. A good agreement between experimental and calculated vibrational frequencies was obtained, as shown in Figure 1 for ligand $\mathbf{1}$ and Zn complex $\mathbf{2}$. 


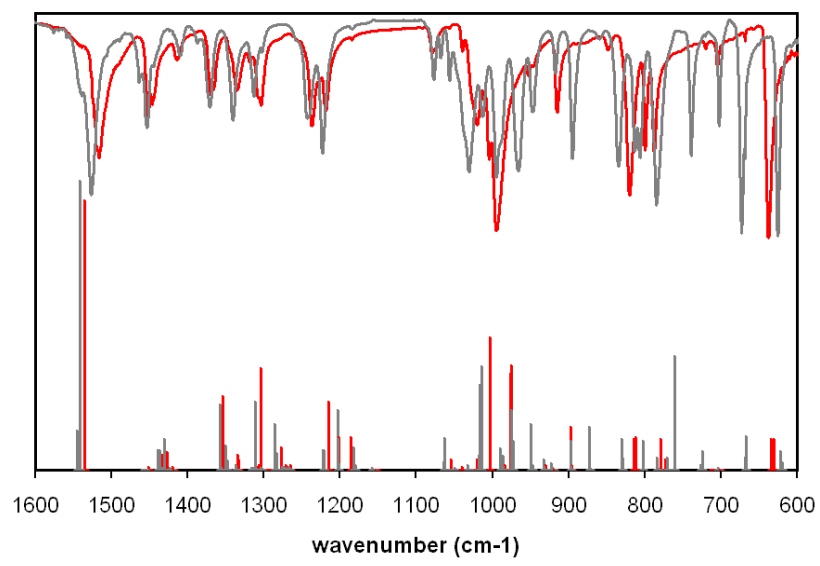

Figure 1. IR spectra of the free ligand $\mathbf{1}$ (red) and the Zn complex $\mathbf{2}$ (grey), in comparison with the calculated (B3LYP/6-31G*) IR vibrational frequencies (top: experimental transmission spectra; bottom: calculated vibrational frequencies and their respective IR intensities).

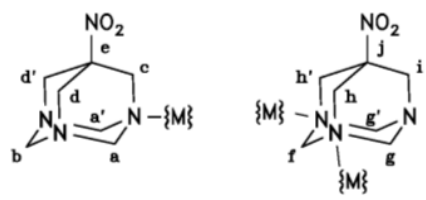

Scheme $3 .{ }^{13} \mathrm{C}$ NMR assignment of the coordinated ligand.

Table $1 .{ }^{13} \mathrm{C}$ MAS-CP coordination shifts $\delta \Delta=\delta$ (complex) - $\delta$ (free ligand) (ppm).

\begin{tabular}{ccccc}
\hline Group & Assignment & & Complex & \\
& & $\mathbf{2}(\mathrm{Zn})$ & $\mathbf{6}(\mathrm{Pd})$ & $\mathbf{7}(\mathrm{Pt})$ \\
\hline $\mathrm{C}_{\mathrm{a}}$ & $\mathrm{e}$ & -1.6 & +2.6 & +1.1 \\
$\mathrm{C}-\mathrm{CH}_{2}-\mathrm{N}-\{\mathrm{M}\}$ & $\mathrm{c}$ & +1.6 & +7.6 & +7.5 \\
$\mathrm{C}-\mathrm{CH}_{2}-\mathrm{N}$ & $\mathrm{d}$ & -0.5 & -1.7 & -1.8 \\
$\mathrm{C}-\mathrm{C} \mathrm{H}_{2}-\mathrm{N}$ & $\mathrm{d}^{\prime}$ & -0.5 & -1.7 & -1.7 \\
$\mathrm{~N}-\mathrm{CH}_{2}-\mathrm{N}-\{\mathrm{M}\}$ & $\mathrm{a}$ & +2.6 & +5.0 & +5.3 \\
$\mathrm{~N}-\mathrm{CH}_{2}-\mathrm{N}-\{\mathrm{M}\}$ & a' & +2.6 & +5.0 & +5.3 \\
$\mathrm{~N}-\mathrm{CH}-\mathrm{N}$ & b & -1.1 & -0.8 & -0.9 \\
\hline
\end{tabular}



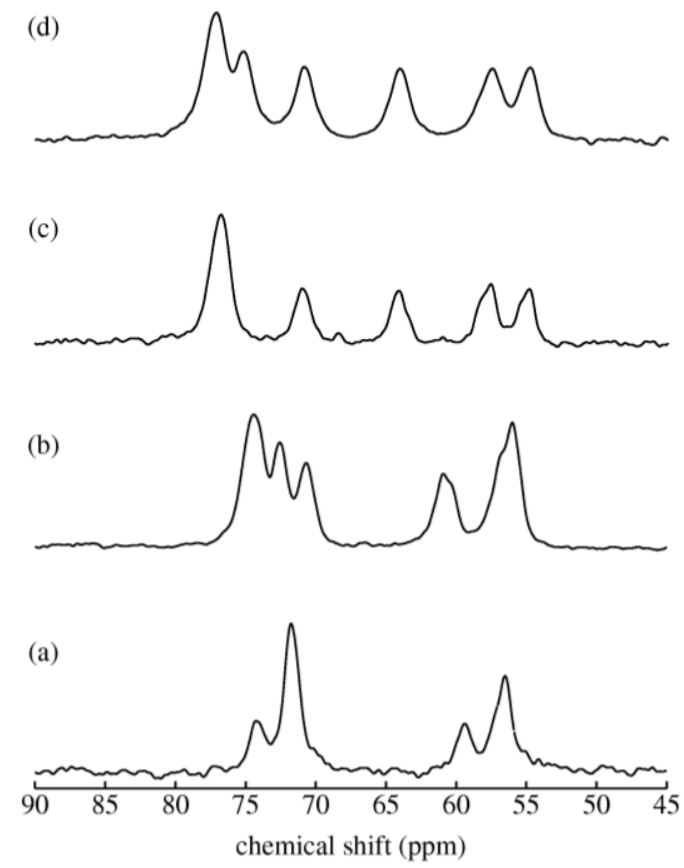

Figure 2. ${ }^{13} \mathrm{C} \mathrm{MAS} / \mathrm{CP}$ spectra of (a) $\mathrm{NO}_{2}-\mathrm{TAA}$ (1), (b) $\left[\mathrm{ZnCl}_{2}\left(\mathrm{NO}_{2}-\mathrm{TAA}\right)_{2}\right]$ (2), (c) $\left[\mathrm{PdCl}_{2}\left(\mathrm{NO}_{2}-\mathrm{TAA}\right)_{2}\right]$ (6), (d) $\left[\mathrm{PtCl}_{2}\left(\mathrm{NO}_{2}-\mathrm{TAA}\right)_{2}\right](7)$.

Overall, the spectra of the isostructural Pd and Pt complexes are quite similar and compare well with those of other $\mathrm{NO}_{2}$-TAA-containing $\mathrm{Pt}(\mathrm{II})$ compounds in solution, where this ligand was shown to bind in a monodentate form. ${ }^{[17]}$ Also the moderately soluble intermediate in the reaction, $\left[\mathrm{PtCl}_{2}(\mathrm{PhCN})\left(\mathrm{NO}_{2}-\mathrm{TAA}\right)\right]$, displays a very similar ${ }^{13} \mathrm{C}$ spectrum for the $\mathrm{NO}_{2}$-TAA moiety. $\mathbf{6}$ and $\mathbf{7}$ could not be analysed in solution due to the poor solubility in all common NMR solvents. The $\mathrm{Zn}(\mathrm{II})$ complex, although the general trends clearly corroborate the monodentate nature of the ligand, shows much smaller coordination shifts and the quaternary $\mathrm{C}-\mathrm{NO}_{2}$ is shifted upfield (rather than downfield as in the Pd and Pt complexes). This reflects the different coordination geometry and also the fact that $\mathrm{Zn}(\mathrm{II})$ is $\mathrm{d}^{10}$-configured, in contrast to the open shell $\mathrm{d}^{8}$ configuration of $\mathrm{Pd}(\mathrm{II})$ and $\mathrm{Pt}(\mathrm{II})$. The small coordination shifts suggest that bonding is relatively weak, in agreement with the reported existence of a labile 1:1 complex in solution. ${ }^{[16]}$

In an attempt to rationalise the observed coordination shifts, GIAO calculations (B3LYP/6-311++G**) were undertaken of the free ligand $\mathbf{1}$, its $\mathrm{BH}_{3}$ complex as an example of a Lewis acid without $\mathrm{d}$-shell interactions, and the tetrahedral $\mathrm{Zn}$ complex $\mathbf{2}$ as compared to the (theoretical) square planar one. In the latter case, full geometry optimisation with $\mathrm{C} 1$ symmetry gave the tetrahedral form, whereas constraint geometry optimisation to $\mathrm{Ci}$ symmetry enforced the square planar coordination geometry (Figure 3 ). As expected for a $\mathrm{d}^{10}$ cation, the tetrahedral $\mathrm{Zn}$ complex is more stable than the square planar one $\left(\Delta \mathrm{E}=22 \mathrm{kcal} / \mathrm{mol}\right.$ with $\mathrm{B} 3 \mathrm{LYP} / 6-31 \mathrm{G}^{*}, 33.2$ $\mathrm{kcal} / \mathrm{mol}$ with B3LYP/6-311++G**).

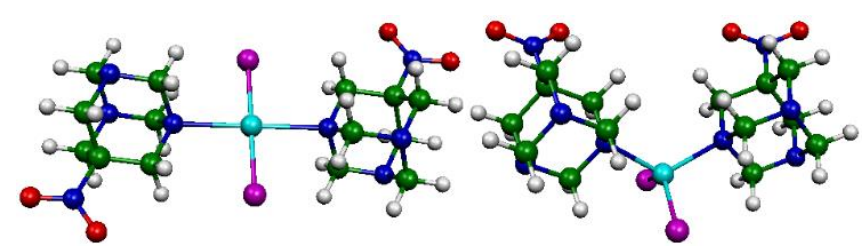

Figure 3. B3LYP/6-311++G** calculated structure of the $\mathrm{Zn}(\mathrm{II})$ complex with a square planar (left) and tetrahedral (right) coordination geometry. 
Table 2. GIAO (B3LYP/6-311++G**) calculated ${ }^{13} \mathrm{C}$ coordination shifts $\delta \Delta=\delta$ (complex) - $\delta$ (free ligand) (ppm).

\begin{tabular}{lcccc}
\hline Group & Assignment & & \multicolumn{2}{c}{ Complex with } \\
& & $\mathrm{BH}_{3}$ & Zn tetrahedral & Zn square planar \\
\hline $\mathrm{C}_{\mathrm{q}}$ & $\mathrm{e}$ & +0.6 & -1.6 & +1.8 \\
$\mathrm{C}-\mathrm{CH}_{2}-\mathrm{N}-\{\mathrm{M}\}$ & $\mathrm{c}$ & +0.4 & +0.5 & +3.9 \\
$\mathrm{C}-\mathrm{CH}_{2}-\mathrm{N}$ & $\mathrm{d}$ & -1.4 & -0.9 & -0.2 \\
$\mathrm{C}-\mathrm{CH}_{2}-\mathrm{N}$ & d' & -2.2 & -2.5 & -0.9 \\
$\mathrm{~N}-\mathrm{CH}_{2}-\mathrm{N}-\{\mathrm{M}\}$ & a & +3.8 & -1.0 & -2.0 \\
$\mathrm{~N}-\mathrm{CH}_{2}-\mathrm{N}-\{\mathrm{M}\}$ & a' & +3.9 & -1.3 & -2.4 \\
$\mathrm{~N}-\mathrm{CH}_{2}-\mathrm{N}$ & b & -2.8 & -2.8 & -3.0 \\
\hline \hline
\end{tabular}

The calculated coordination shifts are given in Table 2. The trends obtained for the $\mathrm{BH}_{3}$ complex match well with the experimental data obtained for the Zn complex, suggesting that the $\mathrm{Zn}$ (II) ion acts essentially as a Lewis acid and the presence of the closed d-shell does not affect the NMR spectrum overly much. This is not the case in the Pd and Pt complexes, whose ${ }^{13} \mathrm{C}$ MAS-CP spectra are clearly different. The calculated data for the $\mathrm{Zn}$ complexes agree reasonably well with the experiment, considering several issues: A more accurate description of the $\mathrm{Zn}$ atom can be expected with a higher level method and basis set, but this will not overcome other intrinsic difficulties. Due to the existence of rotamers with respect to the $\mathrm{Zn}-\mathrm{N}$ axes, there are a significant number of local minima of similar energy but different NMR chemical shifts, the weighted average of which should reflect the solution spectrum. However, packing effects and intermolecular interactions in the solid state will further modify the chemical shift, as compared to the calculation of a single molecule in the gas phase. Still, the calculated spectra of the tetrahedral and square planar forms are relatively similar, except for the signal of the $\mathrm{C}_{\mathrm{q}}$ next to the $\mathrm{NO}_{2}$ group. Here, the agreement of the tetrahedral structure with the experimental value is significantly better, whereas the value for the square planar structure resembles that of the $\mathrm{Pd}$ and $\mathrm{Pt}$ complexes. Since this carbon is very remote from the coordination site, the coordination geometry should have a higher influence on its chemical shift than the presence of the individual metal.

In the ${ }^{15} \mathrm{~N}$ MAS/CP spectra of the $\mathrm{Zn}(\mathrm{II}), \mathrm{Pd}(\mathrm{II})$ and $\mathrm{Pt}(\mathrm{II})$ complexes two amine signals were detected (Figure 4), while the $\mathrm{NO}_{2}$ group did not show, for reasons discussed above. Compared to the amine resonance of the uncoordinated $\mathrm{NO}_{2}-\mathrm{TAA}(1)$ at $28.4 \mathrm{ppm}$, the signals of $\left[\mathrm{ZnCl}_{2}\left(\mathrm{NO}_{2}-\mathrm{TAA}\right)_{2}\right](2)$ appear slightly upfield $(27.0 \mathrm{ppm}$ and $23.7 \mathrm{ppm})$. The coordination shifts $\Delta \delta$ of -1.4 and $-4.7 \mathrm{ppm}$ are quite small and confirm the weak influence of the metal. The inner sphere complexes $\left[\mathrm{PdCl}_{2}\left(\mathrm{NO}_{2}-\mathrm{TAA}\right)_{2}\right]$ (5) and $\left[\mathrm{PtCl}_{2}\left(\mathrm{NO}_{2}-\mathrm{TAA}\right)_{2}\right]$ (6) show very characteristic ${ }^{15} \mathrm{~N}$ spectra, with the coordinated nitrogen far upfield and the uncoordinated ones slightly downfield of the signal of the free ligand. In 5, signals are at 35.4 and $-13.2 \mathrm{ppm}$, to give coordination shifts $\Delta \delta$ of +7.0 and $-41.6 \mathrm{ppm}$. The corresponding peaks of 6 are at 33.1 and $-15.1 \mathrm{ppm}$, resulting in $\Delta \delta$ of +4.7 and $43.5 \mathrm{ppm}$. This is in good agreement with the ${ }^{15} \mathrm{~N}$ NMR solution spectra of $\left[\mathrm{MCl}_{2}\right.$ (n-hexylamine) $\left.{ }_{2}\right]$ complexes described in the literature, where a similar coordination effect was observed. ${ }^{\left[{ }^{[1]}\right.}$ For $\mathrm{M}=\mathrm{Pd}$ and $\mathrm{Pt}, \delta$ is -26.5 and $-37.9 \mathrm{ppm}$ ( $\Delta \delta$ vs. free $\mathrm{n}$-alkylamine ${ }^{[28]}$ is -28.5 and $-39.9 \mathrm{ppm}$ ), respectively. The fact that only one $\mathrm{N}$ experiences a similar upfield shift in our compounds confirms the monodentate binding of $\mathrm{NO}_{2}$-TAA in $\mathbf{5}$ and $\mathbf{6}$.

GIAO calculations (B3LYP/6-311++G**) exactly reproduce the ${ }^{15} \mathrm{~N}$ chemical shift of the ligand $(27.9,27.9,29.3$ ppm, average $28.4 \mathrm{ppm}$, as compared to 28.4 as the experimental value), and also the calculated values for the tetrahedral $\mathrm{Zn}$ complex $(27.1,24.2$ and $24.1 \mathrm{ppm})$ agree quite well with the ones found in the experiment (27.0 
and $23.7 \mathrm{ppm}$ ). The ${ }^{15} \mathrm{~N}$ signals of the square planar $\mathrm{Zn}$ complex are predicted at 41.2, 21.9 and $22.3 \mathrm{ppm}$, which is clearly incompatible with $\mathbf{2}$ or $\mathbf{5}$ and $\mathbf{6}$. The square planar geometry alone is therefore not decisive for the NMR chemical shift but the electronic configuration plays a major role. This can be seen from the calculated data of the hypothetical $\mathrm{NiCl}_{2}\left(\mathrm{NO}_{2}-\mathrm{TAA}\right)_{2}$ complex whose planar geometry was enforced by imposing an electronic singlet state. Here all chemical shifts seem to have a large systematic error of approx. $20 \mathrm{ppm}$, but the ${ }^{15} \mathrm{~N}$ values of $-29.5,7.4$ and $7.8 \mathrm{ppm}$ show the same trends as observed in the Pd and Pt complexes, namely the strong upfield shift of the coordinated nitrogen and the very large $\Delta \delta$ between coordinated and uncoordinated nitrogens. The ${ }^{15} \mathrm{~N}$ data of the $\mathrm{BH}_{3}$ complex $(22.5,24.8$ and $25.8 \mathrm{ppm})$ resembles that of the tetrahedral $\mathrm{Zn}$ complex quite closely, suggesting that the $\mathrm{Zn}(\mathrm{II})$ ion acts essentially as a Lewis acid and the presence of the closed $d$-shell has little effect on the ${ }^{15} \mathrm{~N}$ chemical shifts.

The calculations also allow the prediction of the ${ }^{15} \mathrm{~N}$ chemical shifts of the nitro group which was not observed in the experiment. Thus, the signal of the free ligand should be at $387.4 \mathrm{ppm}$, and those of the complexes with $\mathrm{BH}_{3}$ or $\mathrm{Zn}$ (tetrahedral) at 379.5 and $384.6 \mathrm{ppm}$, respectively. These are at lower field than in simple aliphatic nitro compounds (e.g. $\mathrm{CH}_{3} \mathrm{NO}_{2}: 359.6 \mathrm{ppm}$ on the $\mathrm{NH}_{4} \mathrm{NO}_{3}$ scale) and coordination to a Lewis acid seems to cause an upfield shift, although the effect is small.
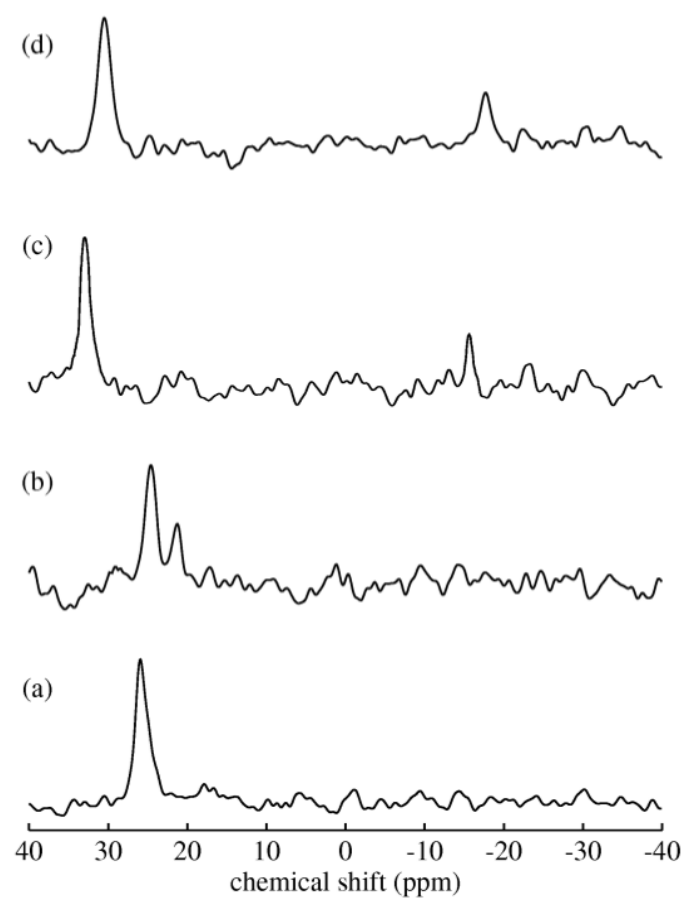

Figure 4. ${ }^{15} \mathrm{~N}$ MAS/CP spectra of (a) $\mathrm{NO}_{2}-\mathrm{TAA}(\mathbf{1}),\left(\right.$ b) $\left[\mathrm{ZnCl}_{2}\left(\mathrm{NO}_{2}-\mathrm{TAA}\right)_{2}\right]$ (2), (c) $\left[\mathrm{PdCl}_{2}\left(\mathrm{NO}_{2}-\mathrm{TAA}\right)_{2}\right]$ (6), (d) $\left[\mathrm{PtCl}_{2}\left(\mathrm{NO}_{2}-\mathrm{TAA}\right)_{2}\right](7)$.

(c) X-ray crystallography: The $\mathrm{Co}(\mathrm{II})$ and $\mathrm{Ni}(\mathrm{II})$ complexes $\mathbf{4}$ and $\mathbf{5}$ were analysed by single crystal $\mathrm{X}$-ray diffraction (Figure 5, Tables $3-5$ ). The two compounds are isostructural, thus only the Ni complex is discussed here. The $\mathrm{Ni}$ atom defines the crystallographic inversion centre in the molecular structure and displays a slightly distorted octahedral coordination geometry. Aqua-, chloro- and $\mathrm{NO}_{2}$-TAA ligands occupy mutual trans positions and $\mathrm{NO}_{2}$-TAA coordinates through one of its amino nitrogens only. The $\mathrm{N}-\mathrm{C}$ bonds involving the coordinated $\mathrm{N}$ are slightly longer than those further away from the coordination site, in good agreement with the calculated structures of the $\mathrm{BH}_{3}$ and the $\mathrm{Zn}$ complexes discussed above.

The coordinated water molecules form intermolecular hydrogen bonds with the chloro ligands, giving rise to infinite two dimensional layers extending through the crystal, as shown in Figure 6 . Parallel $\mathrm{Ni} / \mathrm{Cl} / \mathrm{H}_{2} \mathrm{O}$ layers are separated from each other by two layers formed of coordinated $\mathrm{NO}_{2}$-TAA ligands. Figure 7 shows details of the hydrogen bonding pattern, in which two different ring motifs can be recognised. One consists of Ni-Cl-H-O-Ni$\mathrm{Cl}-\mathrm{H}-\mathrm{O}$ eight membered rings $\left(\mathrm{R}^{2}{ }_{2}(8)\right.$ in Etter's graph set nomenclature $\left.{ }^{[32]}\right)$, the other is a $\mathrm{R}^{2}{ }_{4}(8)$ pattern of eight 
membered $\mathrm{Cl}-\mathrm{H}-\mathrm{O}-\mathrm{H}-\mathrm{Cl}-\mathrm{H}-\mathrm{O}-\mathrm{H}$ rings. The involvement of aqua ligands as proton donors is normal, but the role of the chloro ligands as acceptors for two protons, in the presence of amino and nitro groups, is unexpected at first sight. However, the fact that no hydrogen bonds to the free amines of the $\mathrm{NO}_{2}$-TAA ligand exist can be explained from the exceptionally low basicity of this compound, ${ }^{[18]}$ which should even further decrease upon coordination to a Lewis acidic metal center.

The structures of closely related transition metal complexes bearing other azaadamantane ligands such as hmta or 7-phospha-1,3,5-triazaadamantane show an entirely different behaviour in that $\mathrm{H}$-bonding to the uncoordinated amines is regularly observed. For example, the free amines of the 7-phospha-1,3,5triazaadamantane ligand in $\left[\mathrm{MnCl}_{2}\left(\mathrm{H}_{2} \mathrm{O}\right)\left(\mathrm{C}_{6} \mathrm{H}_{12} \mathrm{~N}_{3} \mathrm{P}\right)_{2}\right]$ form intermolecular hydrogen bonds with the aqua ligands, ${ }^{[13 a]}$ and so does the hmta ligand in $\left[\mathrm{MnCl}_{2}\left(\mathrm{H}_{2} \mathrm{O}\right)(\mathrm{hmta})_{2}\right]^{[33,13 a]}$ and in $\left[\mathrm{Ni}(\mathrm{SCN})_{2}\left(\mathrm{H}_{2} \mathrm{O}\right)_{2}(\mathrm{hmta})_{2}\right]^{[34]}$ The involvement of hmta in hydrogen bonding networks is also well established in cases where hmta is not coordinated but co-crystallised with suitable transition metal complexes. ${ }^{[10]}$ This has not been observed with $\mathrm{NO}_{2}$-TAA so far.
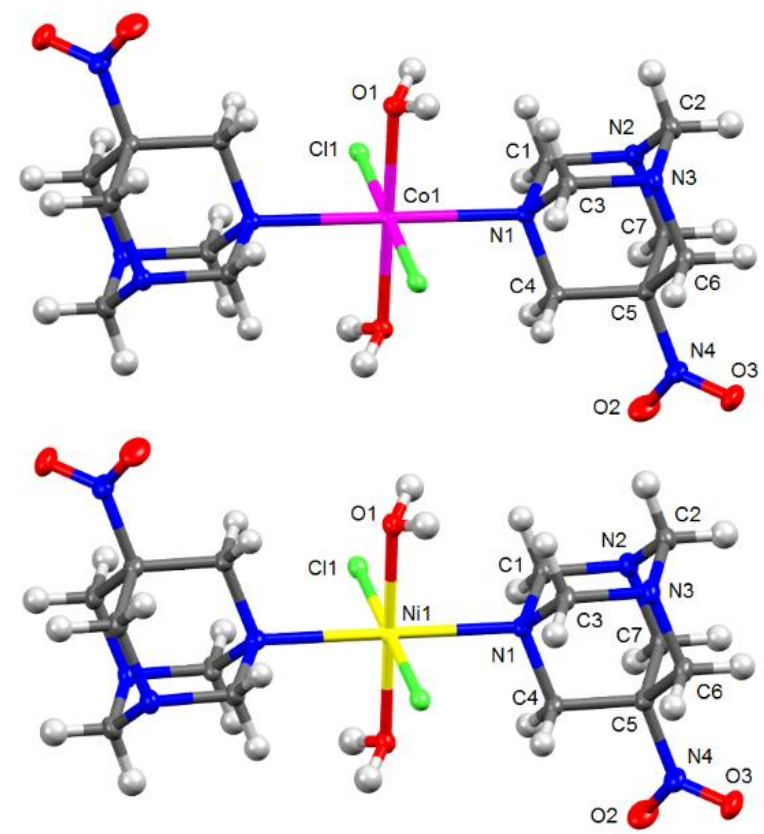

Figure 5. The molecular structure of $\left[\mathrm{CoCl}_{2}\left(\mathrm{H}_{2} \mathrm{O}\right)_{2}\left(\mathrm{NO}_{2}-\mathrm{TAA}\right)_{2}\right](4)$ and $\left[\mathrm{NiCl}_{2}\left(\mathrm{H}_{2} \mathrm{O}\right)_{2}\left(\mathrm{NO}_{2}-\mathrm{TAA}\right)_{2}\right](5)$ with atom numbering scheme. Thermal ellipsoids at the $50 \%$ probability level.

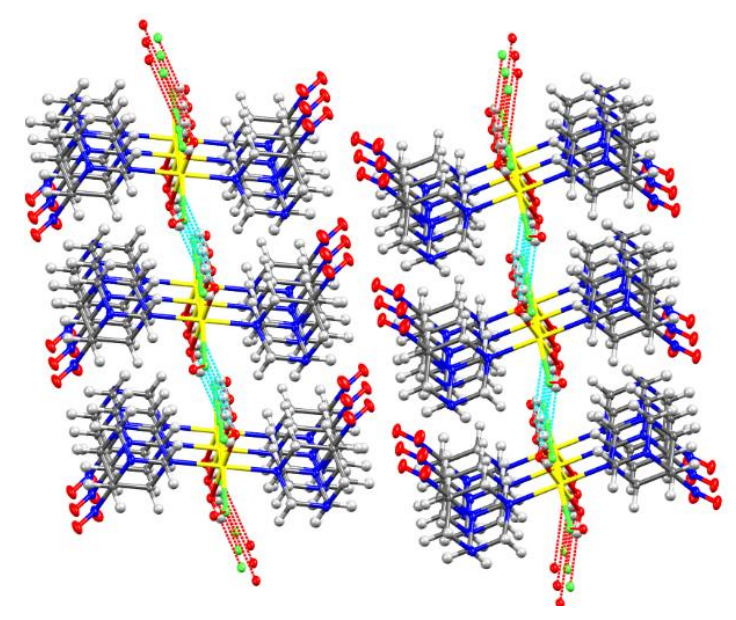

Figure 6. Packing of $\left[\mathrm{NiCl}_{2}\left(\mathrm{H}_{2} \mathrm{O}\right)_{2}\left(\mathrm{NO}_{2}-\mathrm{TAA}\right)_{2}\right](5)$ in the solid state. 


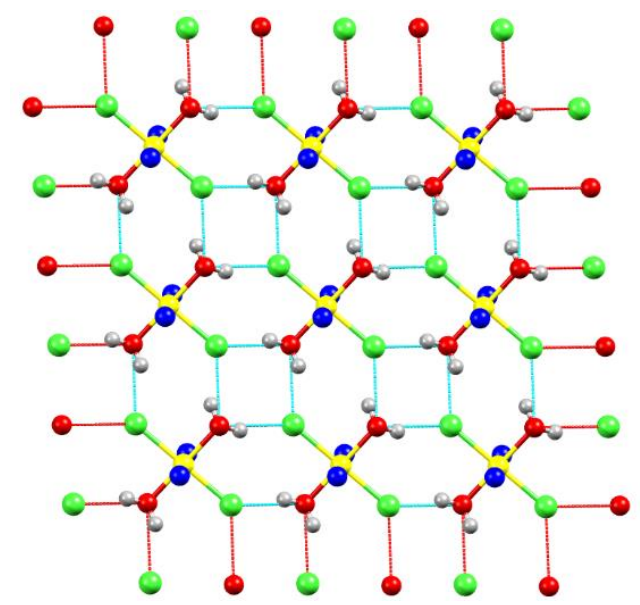

Figure 7. Hydrogen bonding pattern in the structure of $\left[\mathrm{NiCl}_{2}\left(\mathrm{H}_{2} \mathrm{O}\right)_{2}\left(\mathrm{NO}_{2}-\mathrm{TAA}\right)_{2}\right](5)$. The atoms of the $\mathrm{NO}_{2}-\mathrm{TAA}$ ligands, apart from the coordinated $\mathrm{N}(1)$ atom, were omitted for clarity.

Table 3. Selected bond lengths $(\AA ̊)$ and angles $\left({ }^{\circ}\right)$ for $\left[\mathrm{CoCl}_{2}\left(\mathrm{H}_{2} \mathrm{O}\right)_{2}\left(\mathrm{NO}_{2}-\mathrm{TAA}\right)_{2}\right](4)$.

\begin{tabular}{|c|c|c|c|}
\hline $\mathrm{Co}(1)-\mathrm{Cl}(1)$ & $2.4203(5)$ & $N(3)-C(6)$ & $1.467(3)$ \\
\hline $\mathrm{Co}(1)-\mathrm{O}(1)$ & $2.0477(15)$ & $N(4)-C(5)$ & $1.499(3)$ \\
\hline $\mathrm{Co}(1)-\mathrm{N}(1)$ & $2.3358(18)$ & $C(4)-C(5)$ & $1.535(3)$ \\
\hline $\mathrm{O}(2)-\mathrm{N}(4)$ & $1.223(3)$ & $C(5)-C(6)$ & $1.527(3)$ \\
\hline $\mathrm{O}(3)-\mathrm{N}(4)$ & $1.216(3)$ & $C(5)-C(7)$ & $1.534(3)$ \\
\hline$N(1)-C(1)$ & $1.489(3)$ & $\mathrm{O}(1)-\mathrm{H}(1 \mathrm{~A})$ & 0.893 \\
\hline$N(1)-C(3)$ & $1.501(3)$ & $\mathrm{H}(1 \mathrm{~A})-\mathrm{Cl}(1)^{1}$ & 2.25 \\
\hline$N(1)-C(4)$ & $1.482(3)$ & $\mathrm{O}(1)-\mathrm{Cl}(1)^{1}$ & $3.0709(16)$ \\
\hline$N(2)-C(1)$ & $1.458(3)$ & $\mathrm{O}(1)-\mathrm{H}(1 \mathrm{~B})$ & 0.893 \\
\hline$N(2)-C(2)$ & $1.466(3)$ & $\mathrm{H}(1 \mathrm{~B})-\mathrm{Cl}(1)^{2}$ & 2.24 \\
\hline$N(2)-C(7)$ & $1.466(3)$ & $\mathrm{O}(1)-\mathrm{Cl}(1)^{2}$ & $3.1023(16)$ \\
\hline$N(3)-C(2)$ & $1.461(3)$ & $\mathrm{O}(1)-\mathrm{H}(1 \mathrm{~A})-\mathrm{Cl}(1)^{1}$ & 152.9 \\
\hline$N(3)-C(3)$ & $1.451(3)$ & $\mathrm{O}(1)-\mathrm{H}(1 \mathrm{~B})-\mathrm{Cl}(1)^{2}$ & 162.4 \\
\hline
\end{tabular}

${ }^{1} x-1, y, z ;{ }^{2}-x,-y+1,-z$ 
Table 4. Selected bond lengths $(\AA)$ and angles $\left(^{\circ}\right)$ for $\left[\mathrm{NiCl}_{2}\left(\mathrm{H}_{2} \mathrm{O}\right)_{2}\left(\mathrm{NO}_{2}-\mathrm{TAA}\right)_{2}\right](5)$.

\begin{tabular}{|c|c|c|c|}
\hline $\mathrm{Ni}(1)-\mathrm{Cl}(1)$ & $2.3651(6)$ & $N(3)-C(6)$ & $1.459(4)$ \\
\hline $\mathrm{Ni}(1)-\mathrm{O}(1)$ & $2.0307(18)$ & $N(4)-C(5)$ & $1.491(3)$ \\
\hline $\mathrm{Ni}(1)-\mathrm{N}(1)$ & $2.285(2)$ & $C(4)-C(5)$ & $1.531(3)$ \\
\hline $\mathrm{O}(2)-\mathrm{N}(4)$ & $1.217(3)$ & $C(5)-C(6)$ & $1.517(4)$ \\
\hline $\mathrm{O}(3)-\mathrm{N}(4)$ & $1.213(3)$ & $C(5)-C(7)$ & $1.530(4)$ \\
\hline$N(1)-C(1)$ & $1.485(3)$ & $\mathrm{O}(1)-\mathrm{H}(1 \mathrm{~A})$ & 0.89 \\
\hline$N(1)-C(3)$ & $1.490(3)$ & $\mathrm{H}(1 \mathrm{~A})-\mathrm{Cl}(1)^{1}$ & 2.24 \\
\hline$N(1)-C(4)$ & $1.476(3)$ & $\mathrm{O}(1)-\mathrm{Cl}(1)^{1}$ & $3.108(2)$ \\
\hline$N(2)-C(1)$ & $1.451(3)$ & $\mathrm{O}(1)-\mathrm{H}(1 \mathrm{~B})$ & 0.89 \\
\hline$N(2)-C(2)$ & $1.460(4)$ & $\mathrm{H}(1 \mathrm{~B})-\mathrm{Cl}(1)^{2}$ & 2.25 \\
\hline$N(2)-C(7)$ & $1.458(4)$ & $\mathrm{O}(1)-\mathrm{Cl}(1)^{2}$ & $3.079(2)$ \\
\hline$N(3)-C(2)$ & $1.450(4)$ & $\mathrm{O}(1)-\mathrm{H}(1 \mathrm{~A})-\mathrm{Cl}(1)^{1}$ & 163.7 \\
\hline$N(3)-C(3)$ & $1.447(3)$ & $\mathrm{O}(1)-\mathrm{H}(1 \mathrm{~B})-\mathrm{Cl}(1)^{2}$ & 153.7 \\
\hline
\end{tabular}

${ }^{1} x, y, z+1 ;{ }^{2} 1-x, 1-y,-z$

Table 5. Crystallographic data of $\left[\mathrm{CoCl}_{2}\left(\mathrm{H}_{2} \mathrm{O}\right)_{2}\left(\mathrm{NO}_{2}-\mathrm{TAA}\right)_{2}\right](4)$ and $\left[\mathrm{NiCl}_{2}\left(\mathrm{H}_{2} \mathrm{O}\right)_{2}\left(\mathrm{NO}_{2}-\mathrm{TAA}\right)_{2}\right](5)$.

\begin{tabular}{lll}
\hline Empirical formula & $\mathrm{C}_{14} \mathrm{H}_{28} \mathrm{Cl}_{2} \mathrm{CoN}_{8} \mathrm{O}_{6}$ & $\mathrm{C}_{14} \mathrm{H}_{28} \mathrm{Cl}_{2} \mathrm{~N}_{8} \mathrm{NiO}_{6}$ \\
FW & 534.27 & 534.05 \\
Colour/Shape & Purple prism & Yellow block \\
Size/mm & $0.10 \times 0.09 \times 0.07$ & $0.09 \times 0.08 \times 0.05$ \\
Space group & $\mathrm{P} 21 / \mathrm{n}($ no. 14) & $\mathrm{P} 21 / \mathrm{n}(\mathrm{no.} .14)$ \\
$a / \AA$ & $6.0726(3)$ & $6.0310(4)$ \\
$b / \AA$ & $27.3223(11)$ & $27.0739(14)$ \\
$c / \AA$ & $6.1095(2)$ & $6.0512(4)$ \\
$\alpha /{ }^{\circ}$ & 90 & 90
\end{tabular}




\begin{tabular}{|c|c|c|}
\hline $6 /^{\circ}$ & $95.396(4)$ & $90.262(6)$ \\
\hline$y /^{\circ}$ & 90 & 90 \\
\hline$V / \AA^{3}$ & 1009.19(7) & $983.88(10)$ \\
\hline$z, Z^{\prime}$ & $2 / 0.5$ & $2 / 0.5$ \\
\hline$D_{\text {calc. }} / \mathrm{g} \mathrm{cm}^{-3}$ & 1.758 & 1.803 \\
\hline$\mu(\mathrm{Mo}-\mathrm{K} \alpha) / \mathrm{mm}^{-1}$ & 1.169 & 1.312 \\
\hline$R_{1}{ }^{a}$ & 0.0385 & 0.0349 \\
\hline$w R_{2}{ }^{b}$ & 0.1106 & 0.0933 \\
\hline${ }^{\mathrm{a}} R_{1}=\Sigma|| F_{o}|-| F_{c}|| / \Sigma\left|F_{o}\right|$. & \multicolumn{2}{|c|}{${ }^{\mathrm{b}} w R_{2}=\left\{\Sigma\left[w\left(\mathrm{Fo}_{0}^{2}-\mathrm{F}_{\mathrm{c}}^{2}\right)^{2}\right] / \Sigma\left[w\left(\mathrm{~F}_{0}^{2}\right)^{2}\right]\right\}^{1 / 2}$} \\
\hline
\end{tabular}

\section{Conclusions}

In conclusion, we have shown that $\mathrm{NO}_{2}$-TAA forms mononuclear transition metal complexes, readily and selectively. Metal coordination to one of the nitrogen atoms deactivates the other two, and this prevents not only the coordinating to other metal centres but also protonation and the formation of hydrogen bonds with proton donors. In this light, $\mathrm{NO}_{2}$-TAA is certainly not an ideal ligand for metal organic framework applications where poly-dentate binding to several metal centres is essential. The $\mathrm{NO}_{2}$-TAA ligand, however, should to be well suited as a weak and exchangeable ligand for catalytic applications due to its relatively weak binding to transition metals, accompanied with kinetic lability in many cases. Here one might envisage reactions such as the $\mathrm{PtCl}_{2}(\mathrm{PhCN})_{2}$ catalysed cascade reactions of bis-alkynes described in the literature, ${ }^{[35]}$ among others. Another option could be in the field of medicinal applications, e.g. in the form of cytotoxic Pt compounds where a certain degree of ligand lability is desired. This has recently been proposed ${ }^{[17]}$ and a number of mixed ligand $\mathrm{Pt}(\mathrm{II})$ complexes with $\mathrm{NO}_{2}$-TAA have been synthesised. ${ }^{[18]}$ These complexes are more cytotoxic in in-vitro experiments than structurally related platinum complexes that do not bear the NO${ }_{2}$-TAA moiety. ${ }^{\left[{ }^{[6]}\right]}$ The triazaadamantane structure is particularly promising because the substituent in 7-position (and potentially other positions in the framework) can be chemically modified and so the charge density at the amino nitrogens, and consequently the coordination behaviour, can be fine-tuned to purpose. Work in this sense is in progress in our group.

\section{Supporting Information}

Supporting information for this article contains details of experimental procedures and the synthesis and characteristion of all compounds. CCDC- 1455253 and CCDC-1455254 contain the supplementary crystallographic data for this paper. These data can be obtained free of charge from The Cambridge Crystallographic Data Centre via http://www.ccdc.cam.ac.uk/data request/cif

\section{Acknowledgements}

Johnson-Matthey PIc (Sonning Common, UK) is gratefully acknowledged for a generous loan of Pt and Pd compounds, and the University of Chester for general support of this work. 
Keywords: Transition metals $\bullet$ coordination modes $\bullet N$-ligands $\bullet$ solid state NMR $\bullet$ hydrogen bonding network

\section{References:}

[1] H.-D. Martin, B. Mayer, Angew. Chem. 1983, 95, 281-313; Angew. Chem. Int. Engl. Ed. 1983, 22, 283-314.

[2] a) L. Meurling, Chem. Scr. 1975, 7, 23-30. b) A. P. Cooney, M. R. Crampton, P. Golding, J. Chem. Soc. Perkin Trans. // 1986, 835-839.

[3] H. K. Hall Jr., J. Am. Chem. Soc. 1957, 79, 5441-5444.

[4] D. H. Everett, W. F. K. Wynne-Jones, Proc. Roy. Soc. (London), 1938, 169, 190-204.

[5] a) M. Bertelli, L. Carlucci, G. Ciani, D. M. Proserpio, A. Sironi, J. Mater. Chem. 1997, 7, 1271-1276. b) L. Carlucci, G. Ciani, D. M. Proserpio, A. Sironi, Inorg. Chem. 1997, 36, 1736-1737. c) L. Carlucci, G. Ciani, D. v. Gudenberg, D. M. Proserpio, A. Sironi, Chem. Commun. 1997, 631-632. d) M.-L. Tong, S.-L.Zheng, X.-M.Chen, Chem. Eur. J. 2000, 6, 3729-3738. e) S.-L. Zheng, M.-L.Tong, H.-L.Zhu, Y. Fang, X.-M. Chen, Dalton Trans. 2001, 20492053. f) S.-L. Zheng, M.-L. Tong, R.-W. Fu, X.-M. Chen, S.-W. Ng, Inorg. Chem. 2001, 40, 3562-3569.

[6] a) M. L. Tong, S. L. Zheng, X. M. Chen, Chem. Eur. J. 2000, 6, 3729-3738. b) T. C. W. Mak, Inorg. Chim. Acta 1984, 84, 19-23.

[7] A. Michelet, B. Viossat, P. Khodadad, N. Rodier, Acta Cryst. 1981, B37, 2171-2175.

[8] a) J. Pickard, Z. Naturforsch. 1981, B36, 1225-1227. b) J. Pickardt, Acta Cryst. 1981, B37, 1753-1756. c) J. Pickardt, N. Rautenberg, Z. Naturforsch. 1982, B37, 1569-1572. d) B. Viossat, P. Khodadad, N. Rodier, Acta Cryst. 1982, C38, 3075-3078. e) T. C. W. Mak, Z. Kristallogr. 1982, 159, 247-254. f) T.-F. Lai, T. C. W. Mak, Z. Kristallogr. 1983, 165, 105-115. g) T. C. W. Mak, Y.-K. Wu, Inorg. Chim. Acta 1985, 104, 149-153. h) T. C. W. Mak, Y.-K. Wu, Inorg. Chim. Acta 1986, 121, L37-L39.

[9] a) M. Shimoi, A. Ouchi, M. Aikawa, S. Sato, Y. Saito, Bull. Chem. Soc. Jp. 1982, 55, 2089-2093. b) K. J. Hui, P. C. Chan, T. C. W. Mak, Inorg. Chim. Acta 1984, 84, 25-29. c) T. C. W. Mak, S.-H. Huang, Polyhedron 1987, 6, 1111-1114. d) J. Pickardt, P Droas, Acta Cryst. 1989, C45, 360-363. e) P. H. Svensson, L. A. Bengtson-Kloo, H. Stegemann, Acta Cryst. 1995, C51, 2289-2292.

[10] a) L. Mazzarella, A. L. Kovacs, P. de Santis, A. M. Liquori, Acta Cryst. 1967, 22, 65-74. b) F. Dahan, Acta Cryst. 1974, B30, 22-27. c) F. Dahan, Acta Cryst. 1975, B31, 423-426. d) B. Viossat, P. Khodadad, N. Rodier, Bull. Chim. Soc. Fr. 1981, 69-71. e) J. Pickardt, J. Kahler, N. Rautenberg, E. Riedel, Z. Naturforsch. 1984, B39, 1162-1166. f) H.-J. Meyer, J. Pickardt, Z. Anorg. Allg. Chem. 1988, 560, 185-192. g) H.-J. Meyer, J. Pickardt, Acta Cryst. 1988, C44, 1715-1717. h) H.-J. Meyer, J. Pickardt, Z. Naturforsch. 1988, B43, 135-137. i) H.-J. Meyer, J. Pickardt, Z. Naturforsch. 1989, B44, 519525. j) V. Ganesh, M. Seshasayee, G. Aravamundan, D. Heijdenrijk, H. Schenk, Acta Cryst. 1990, C46, 949-951. k) F. Xue, T. C. W. Mak, Struct. Chem. 1996, 7, 253-261. I) Y. Xuan, W. Wu, S. Li, Cryst. Res. Technol. 2009, 44, 127-130.

[11] a) C. Lidrissi, A. Romerosa, M. Saoud, M. Serrano-Ruiz, L. Gonsalvi, M. Peruzzini, Angew. Chem. Int. Engl. Ed. 2005, 44, 2568-2572; Angew. Chem. 2005, 117, 2624-2628. b) M. Serrano-Ruiz, A. Romerosa, B. Sierra-Martin, A. Fernandez-Barbero, Angew. Chem. Int. Engl. Ed. 2008, 47, 8665-8669; Angew. Chem. 2008, 120, 8793-8797. c) M. Koutmos, I. P. Georgakaki, P. Tsiolis, D. Coucouvanis, Z. Anorg. Allg. Chem. 2008, 634, 255-261. d) X. Tu, H. Truong, G. S. Nichol, Z. Zheng, Inorg. Chim. Acta 2010, 363, 4189-4196.

[12] a) B. J. Frost, W.-C. Lee, K. Pal, T. H. Kim, D. VanDerver, D. Rabinovich, Polyhedron 2010, 29, 2373-2380. b) P. Smolenski, A. Kochel, Polyhedron 2010, 29, 1561-1566.

[13] a) B. J. Frost, C. M. Bautista, R. Huang, J. Shearer, Inorg. Chem. 2006, 45, 3481-3483. b) B. J. Frost, J. L. Harkreader, C. M. Bautista, Inorg. Chem. Commun. 2008, 11, 580-583.

[14] S. Diener, A. Santoro, C. A. Kilner, J. J. Loughrey, M. A. Halcrow, Dalton Trans. 2012, 41, 3731-3739.

[15] a) D. A. Durham, F. A. Hart, D. Shaw, J. Inorg. Nucl. Chem. 1967, 29, 509-516. b) J. K. Clegg, J. Harrowfield, Y. Kim, Y. H. Lee, J.-M. Lehn, W. T. Lim, P. Thuéry, Dalton Trans., 2012, 41, 4335-4357.

[16] A. F. Danil de Namor, N. A. Nwogu, J. A. Zvietcovich-Guerra, O. E. Piro, E. E. Castellano, J. Phys. Chem. B 2009, 113, 4775-4780.

[17] G. Wagner, A. Marchant, J. Sayer, Dalton Trans. 2010, 7747-7759.

[18] G. Wagner, S. Sieste, I. Lifincev, N. Stein, J. Dempfle, submitted.

[19] a) E. B. Hodge, J. Org. Chem. 1972, 37, 320-321. b) N. W. Gabel, U.S. patent 3,301,845 (1967), Chem. Abstr. 67:21936 (1967). c) V. Galik, M. Safer, Z. Kafka, S. Landa, Collect. Czech. Chem. Commun. 1975, 40, 442-447.

[20] M. Safer, V. Galik, Z. Kafka, S. Landa, Collect. Czech. Chem. Commun. 1975, 40, 2179-2182.

[21] a) A. Edwards, G. A. Webb, Org. Magnet. Reson. 1978, 11, 103-105. b) A. R. Farminer, G. A. Webb, Org. Magnet. Reson. $1976,8,102-107$.

[22] a) R. E. Taylor, C. Dybowski, J. Mol. Struct. 2008, 889, 376-382. b) E. A. Reyes-Garcia, Y. Sun, K. Reyes-Gil, D. Raftery, J. Phys. Chem. C 2007, 111, 2738-2748. c) S. Kuroki, S. Ando, I Ando, A. Shoji, T. Ozaki, G. A. Webb J. Mol. Struct. 1990, 240, 19-29. d) For general aspects of ${ }^{15} \mathrm{~N}$ NMR referencing, see also: G. E. Martin, C. E. Hadden, J. Nat. Prod. 2000, 63, 543-585.

[23] G. C. Levy, J. J. Dechter, J. Kowalewski, J. Am. Chem. Soc. 1978, 100, 2308-2314.

[24] P. Loftus, W. H. Bearden, J. D. Roberts, Nouv. J. Chim. 1977, 1, 283-285.

[25] G. C. Levy, C. E. Holloway, R. C. Rosanske, J. M. Hewitt, Org. Magnet. Reson. 1976, 8, 643-647.

[26] E. Lippmaa, T. Saluvere, S. Laisaai, Chem. Phys. Lett. 1971, 11, 120-123.

[27] D. Schweitzer, H. W. Spiess, J. Magnet. Reson. 1974, 16, 243-251. 
[28] a) D. Sanz, R. M. Claramunt, M. Á. García, I Alkorta, J. Elguero, Tetrahedron 2011, 67, 4633-4639. b) R. L. Lichter, J. D. Roberts, J. Am. Chem. Soc. 1972, 94, 2495-2500. c) J. P. Warren, J. D. Roberts, J. Phys. Chem. 1974, 78, 2507-2511. d) R. O. Duthaler, J. D. Roberts, J. Am. Chem. Soc. 1978, $100,3889-3895$

[29] S. Bulusu, T. Axenrod, J. R. Autera, Org. Magn. Reson. 1981, 16, 52-56.

[30] O. V. Agashkin, L. M. Shustova, V. A. Kosmakov, A. I. Kuznetsov, B. V. Unkovskii, Doklady Akad. Nauk. SSSR, 1988, 303, 373-376.

[31] H. Motschi, P. S. Pregosin, L. M. Venanzi, Helv. Chim. Acta, 1979, 62, 667-677.

[32] (a) M. C. Etter, Acc. Chem. Res. 1990, 23, 120-126. (b) M. C. Etter, J. Phys. Chem. 1991, 95, 4601-4610.

[33] Y.-C. Tang, J. H. Sturdivant, Acta Cryst. 1952, 5, 74-82.

[34] Y. Zhang, J. Li, M. Nishiura, T. Imamoto, J. Mol. Struct. 2000, 520, 259-263.

[35] (a) M. Lampropoulou, R. Herrmann, G. Wagner; Tetrahedron, 2004, 60, 4635-4643. (b) M. F. N. N. Carvalho, A. J. L. Pombeiro, G. Wagner, B. Pedersen, R. Herrmann; Z. Naturforsch. 1999, 54b, 725-733.

[36] H. M. Coley, J. Sarju, G. Wagner, J. Med. Chem. 2008, 51, 135-141.

[37] S. J. Coles, P. A. Gale, Chem. Sci., 2012, 3, 683-689.

[38] CrystalClear-SM Expert 3.1 b27, 2013, Rigaku

[39] CrysAlisPro 1.171.38.41, 2015, Rigaku Oxford Diffraction.

[40] O. V. Dolomanov, L. J. Bourhis, R. J. Gildea, J. A. K. Howard, H. Puschmann, J. Appl. Cryst., 2009, 42, 339-341.

[41] L. Palatinus, G. Chapuis, J. Appl. Cryst., 2007, 40, 786-790.

[42] G. M. Sheldrick, Acta Cryst., 2015, C71, 3-8.

[43] Gaussian 03, revision A.1, M. J. Frisch, G. W. Trucks, H. B. Schlegel, G. E. Scuseria, M. A. Robb, J. R. Cheeseman, J. A. Montgomery, Jr., T. Vreven, K. N. Kudin, J. C. Burant, J. M. Millam, S. S. Iyengar, J. Tomasi, V. Barone, B. Mennucci, M. Cossi, G. Scalmani, N. Rega, G. A. Petersson, H. Nakatsuji, M. Hada, M. Ehara, K. Toyota, R. Fukuda, J. Hasegawa, M. Ishida, T. Nakajima, Y. Honda, O. Kitao, H. Nakai, M. Klene, X. Li, J. E. Knox, H. P. Hratchian, J. B. Cross, C. Adamo, J. Jaramillo, R. Gomperts, R. E. Stratmann, O. Yazyev, A. J. Austin, R. Cammi, C. Pomelli, J. W. Ochterski, P. Y. Ayala, K. Morokuma, G. A. Voth, P. Salvador, J. J. Dannenberg, V. G. Zakrzewski, S. Dapprich, A. D. Daniels, M. C. Strain, O. Farkas, D. K. Malick, A. D. Rabuck, K. Raghavachari, J. B. Foresman, J. V. Ortiz, Q. Cui, A. G. Baboul, S. Clifford, J. Cioslowski, B. B. Stefanov, G. Liu, A. Liashenko, P. Piskorz, I. Komaromi, R. L. Martin, D. J. Fox, T. Keith, M. A. Al_Laham, C. Y. Peng, A. Nanayakkara, M. Challacombe, P. M. W. Gill, B. Johnson, W. Chen, M. W. Wong, C. Gonzalez, J. A. Pople, Gaussian, Inc., Pittsburgh PA, 2003.

[44] P. Flükiger, H. P. Lüthi, S. Portmann, J. Weber, MOLEKEL 4.0, Swiss Center for Scientific Computing, Manno (Switzerland), 2000 